\title{
IMPLEMENTASI PENANAMAN NILAI-NILAI RELIGIUS PADA ANAK USIA DINI DI TK DHARMA WANITA TIBO KECAMATAN SINDUE TOMBUSABORA KABUPATEN DONGGALA
}

\author{
Siti Julianti ${ }^{1)}$ Rustam $^{2)}$ Kasmiati ${ }^{3)}$ \\ ${ }^{1}$ Mahasiswa Program Studi PIAUD FTIK Institut Agama Islam Negeri Palu \\ ${ }^{2}$ Dosen Fakultas Tarbiyah dan Ilmu Keguruan Institut Agama Islam Negeri Palu \\ ${ }^{3}$ Dosen Fakultas Tarbiyah dan Ilmu Keguruan Institut Agama Islam Negeri Palu
}

\begin{abstract}
ABSTRAK
Penelitian ini membahasa tentang implementasi penanaman nilai-nilai religious pada anak usia dini di TK Dharma Wanita Tibo Kecamatan Sindue Tombusabora Kabupaten Donggala. Penelitian ini menggunakan pendekatan kualitatif. Teknik pengumpulan data melalui observasi, wawancara dan dokumentasi. Teknik analisis data yang digunakan adalah reduksi data, penyajian data dan verifikasi data. Berdasarkan hasil penelitian, diperoleh bahwa implementasi penanaman nilai-nilai religious pada anak usia dini di TK Dharma Wanita Tibo Kecamatan Sindue Tombusabora Kabupaten Donggala setelah dilakukannya penanaman nilainilai religious kepada anak-anak dengan mengajarkan nilai keimanan, nilai ibadah dan nilai akhlak, para guru mengajarkan kepada mereka dengan cara berdoa sebeleum memulai belajar, bernyanyi khususnya lagu tentang keagamaan serta sopan santun yang baik.
\end{abstract}

Kata Kunci : Nilai Religius, Anak usia dini.

\section{PENDAHULUAN}

Dalam Undang-undang Republik Indonesia Nomor 20 Tahun 2003 tentang sistem Pendidikan Nasional, pada Bab 1 Pasal 1 bahwa, Pendidikan adalah usaha sadar dan terencana untuk mewujudkan suasana belajar dan proses pembelajaran agar peserta didik secara aktif mengembangkan potensi dirinya untuk memiliki kekuatan spiritual keagamaan, pengendalian diri, kepribadian, kecerdasan, akhlak mulia serta keterampilan yang diperlukan dirinya, masyarakat, bangsa, dan negara. ${ }^{1}$ Setiap satuan pendidikan menyelenggarakan kelompok layanan pada jalur formal, nonformal, dan informal pada setiap jenjang dan pendidikan. Dalam satuan pendidikan anak usia dini layanan pendidikan pada jalur formal berupa taman kanak-kanak (TK). Menanamkan nilai agama merupakan tanggung jawab bersama, sehingga dengan demikian akan

${ }^{1}$ Depertemen Pendidikan Nasional, Undang-undang RI Nomor 20 Tahun 2003, Tentang Sistem Pendidikan Nasional, Pada Bab 1, Pasal 1, (2003). 
tercermin dalam sikap, tingkah laku, dan cara menghadapi persoalan dalam kehidupan pribadinya. Pendidikan sebagai proses pembelajaran harus bertanggung jawab untuk menjadikan seseorang tidak hanya sekedar mengenal nilai-nilai kebaikan semata, melainkan menyandarkan kepada anak untuk mengamalkan nilai-nilai kebaikan tersebut dalam kehidupan sehari-hari sebagai perwujudan karakter atau kepribadian yang mulia.

Banyaknya permasalahan yang sedang terjadi diseluruh aspek kehidupan saat ini tidak terlepas dari pendidikan agama yang kurang tepat karena berfokus pada nilai angka saja, arus liberalisasi yang sulit dibendung dan pemahaman demokratisasi yang berlebihan menimbulkan tingkah laku yang sering bertentangan dengan nilai-nilai agama moral. Indikasinya adalah: 1) Kurangnya rasa hormat terhadap orang tua , guru, teman, dan sebaginya. 2) tidak mau menghargai orang lain. 3) Cenderung bersifat individualistik dan tidak peduli dengan orang lain. 4) Cara berbicara, berpakaian dan bergaul yang kurang sopan atau berprilaku lain yang tidak sesuai dengan nilai-nilai agama.

Salah satu cara yang dapat ditempuh untuk mengatasi permasalahan tersebut adalah dengan membenahi masalah moral anak sedini mungkin, baik dari keluarga, sekolah maupun lingkungan. Dalam melakukan pembinaan moral, maka hal yang paling penting dibenahi adalah agamanya atau religiusnya. Karena agama mencakup totalitas tingkah laku manusia, yang mana apabila agamanya baik, maka seluruh tingkah lakunya akan berlandaskan keimanan dan akan membentuk akhlak karimah yang akan menjadi kebiasaan dalam pribadi dan tingkah lakunya. Apabila nilai-nilai agama telah tertanam kuat pada diri seorang anak maka mereka akan tumbuh dan berkembang dengan memiliki kemampuan untuk mencegah dan menangkal serta membentengi diri mereka dari berbagai pengaruh yang negatif. Sebaliknya jika nilainilai keagamaan itu tidak ditanamkan dan dikembangkan secara maksimal maka yang akan muncul adalah perilaku-perilaku yang kurang baik dan cenderung menyimpang dari aturan agama.

Perkataan religi berasal dari bahasa latin yang tersusun dari dua kata yaitu "re" berarti "kembali" dan "ligire" berarti " terkait atau terikat". Maksudnya adalah bahwa manusia dalam hidupnya tidak bebas menurut kemauannya sendiri, tetapi harus menurut ketentuan hukum karena perlu adanya hukum yamg mengikatnya. Religius adalah sikap dan perilaku yang patuh dalam melaksanakan ajaran agama yang dianutnya, toleran terhadap pelakasanaan ibadah agama lain, dan hidup rukun dengan pemeluk agama lain serta merupakan nilai-nilai dalam ajaran agama yang dijadikan pedoman dalam segala ucapan dan perbuatan seseorang. Adapun nilai-nilai religius meliputi nilai keimanan, ibadah dan akhlak. Nilai-nilai religius tidak dapat diterapkan begitu saja, tapi harus ditanamkan,dilatih, dan dibiasakan sejak usia dini, karena dengan 
latihan-latihan bertambah jelas dan kuat, akhirnya tidak tergoyahkan lagi dan akan menjadi bagian dari dirinya. ${ }^{2}$

Pendidikan anak sejak usia dini tidak saja menjadi kebutuhan setiap orang tua, tetapi juga menjadi perhatian serius dari masyarakat, negara, bahkan menjadi perhatian internasional, hal ini dapat dibuktikan dengan banyaknya program pemerintah yang memfokuskan pada pendidikan anak. seering dengan kebutuhan anak orang tua untuk mendidik anak-anaknya sejak usia dini. Pendidikan harus dapat mencapai seluruh aspek dan segi kehidupan manusia yaitu aspek jasmani dan rohani, aspek fisik dan mental spritual, serta aspek lahiriah dan batiniah. Dengan keseluruhan aspek tersebut tercapai maka dapat dihasilkan manusia yang berilmu dan bermoral, untuk mencetak manusia seperti yang diharapkan salah satu usaha yang dapat dilakukan adalah memberi pendidikan sejak dini.

Anak usia dini adalah masa peka untuk menerima pengaruh dari lingkungannya, hal ini merupakan kesempatan bagi lingkungan, dalam hal ini orang tua, guru, dan sekolah untuk memberikan pengaruh edukatif yang seluas-luasnya kepada anak, agar membantu mengembangkan perilaku anak yang positif. Salah satu pendekatan untuk mendidik iman dan taqwanya adalah pendidikan agama sejak dini. ${ }^{3}$ Anak adalah generasi penerus keluarga dan bangsa yang perlu mendapatkan pendidikan yang baik sehingga potensi-potensi dirinya dapat berkembang dengan sangat pesat, sehingga akan tumbuh menjadi manusia yang memiliki kepribadian yang tangguh dan cakap serta terampil. Oleh karena itu, pentingnya bagi keluarga khususnya orang tua berperan dan bertanggung jawab dalam memberikan macam stimulasi dan bimbingan yang tepat sehingga akan tercipta generasi penerus yang berakhlakul karimah dan bertingkah laku sesuai dengan norma-norma.

Pendidikan taman kanak-kanak memegang peranan yang sangat penting dalam menentukan perkembangan anak selanjutnya. Hal ini disebabkan karena pendidikan anak usia TK merupakan fondasi bagi terbentuknya kepribadian anak. Anak yang ditanamkan keagamaan sejak usia taman kanak-kanak dapat terbiasa melakukan halhal sesuai dengan yang diajarkan, walaupun belum mengembangkan hati nuraninya sehingga anak tidak merasa bersalah bila melakukan sesuatu yang diketahui sebagai sebuah kesalahan melainkan anak hanya takut dengan hukuman dan berusaha membenarkan perbuatannya untuk menghindari hukuman.

Berdasarkan hasil lokakarnya pengembangan pendidikan pra sekolah atau pendidikan anak usia dini penting karena merupakan: 1) periode pembentukan dasar pengetahuan, sikap dan keterampilan, 2) periode yang sangat berpengaruh terhadap kualitas anak pada masa berikutnya, 3) periode untuk melakukan dasar-dasar

\footnotetext{
2 Muhammad Fadilah, Pendidikan Karakter Anak Usia Dini, (Yogyakarta: Ar-Ruzz Media, 2013), 190.

${ }^{3}$ Winda Gunarti, Metode Pengembangan Perilaku dan Kemampuan Dasar Anak Usia Dini, (Jakarta: Penerbit Universitas Terbuka, 2008), 1-3.
} 
keyakinan agama, etika, dan budaya, 4) periode untuk mengembangkan potensi anak, 5) periode yang tidak dapat dikonversikan pada masa mendatang, 6) periode perkembangan hati secara maksimal sehingga faktor gizi dan stimulus yang tepat sangat mempengaruhi. ${ }^{4}$

Penanaman nilai-nilai religius pada anak TK (Taman kanak-kanak) sangat penting karena akan mempengaruhi pada masa remajanya dan bahkan pada masa tua. Pengalaman dan hasil dari penanaman nilai-nilai religius pada anak-anak akan tersimpan dalam pikiran dan hatinya, karena jiwa anak yang masih polos jika diisi dengan nilai-nilai religius maka akan mudah diterima. Sebagaimana Al-Ghazali mengatakan bahwa pendidikan yang utama bagi anak adalah mendidik hati mereka dengan ilmu pengetahuan dan mendidik jiwanya dengan berma'rifat kepada Allah Swt. Semua itu akan terlaksanakan tanpa diawali dengan jalan menanamkan nilai-nilai religius yang benar pada anak semenjak kecil. ${ }^{5}$ Hal inilah yang nantinya menjadi fokus peneletian. Penanaman nilai-nilai moral, budi pekerti dan agama semakin dini akan semakin bagus, karena anak akan lebih cepat mengadopsi ilmu, nilai-nilai yang memang harus dikuasainya. Taman kanak-kanak (TK) menjadi sangat penting peranannya karena sebagai dasar pendidikan selanjutnya, dimana berbagai macam nilai masih muda dimasukkan kedalam pribadi anak dengan berbagai cara misalnya anak diajarkan sopan santun, akhlak yang baik, saling tolong menolong.

Implementasi diartikan sebagai pelaksanaan atau penerapan. Artinya yang dilaksanakan atau diterapkan adalah kurikulum yang telah dirancang atau didesain untuk kemudian dijalankan sepenuhnya. Menurut Nurdin Usman bahwa:

Implementasi adalah bermuara pada aktivitas, aksi, tindakan, atau adanya mekanisme suatu sistem, implementasi bukan sekedar aktivitas, tapi suatu kegiatan yang terencana dan untuk mencapai tujuan kegiatan. ${ }^{6}$

Pada uraian di atas dapat disimpulkan bahwa implementasi adalah bermuara pada aktivitas bukan sekedar sistem. tetapi, suatu tindakan yang akan mendapatkan tujuan tersebut. Sedangkan penanaman nilai berasal dari kata tanam, proses, cara atau menanamkan. Penanaman berarti sebuah upaya atau strategi untuk menanamkan nilainilai akhlak yang baik agar menjadi suatu kebiasaan.Nilai adalah sifat-sifat/hal-hal yang penting yang berguna bagi kemanusian. Pada umumnya nilai erat kaitannya dengan kepercayaan, sikap, atau perasaan yang dibanggakan individu, dipegang teguh dan dipilih karena dilaksanakan terus menerus tanpa adanya paksaan dan menjadi acuan dalam kehidupan individu. Jadi nilai adalah suatu prinsip atau kepercayaan yang menjadi dasar bagi seseorang atau sekelompok orang untuk bertindak

${ }^{4}$ Sri Harini, Mendidik Anak Sejak Dini, (Yogyakarta: Kreasi Wacana, 2003), 85.

5 Fatiyah Hasan Sulaiman, Sistem Pendidikan Versi Al-Ghazali, (Bandung: Al-Ma'arif, 1986), 61.

${ }^{6}$ Nurdin Usman, Konteks Implementasi Berbasis Kurikulum, (Jakarta: Grasindo, 2002), 70. 
Berdasarkan latar belakang tersebut, peneliti ingin mengetahui implementasi dan bentuk penanaman nilai karakter religius pada anak usia dini di TK Dharma Wanita Tibo Kecamatan Sindue Tombusabora Kabupaten Donggala serta faktor pendukung dan penghambatnya.

\section{METODE PENELITIAN}

Jenis penelitian yang digunakan dalam penelitian ini adalah penelitian kualitatif. Lokasi penelitian yakni di TK Dharma Wanita Tibo Kecamatan Sindue Tombusabora Kabupaten Donggala. Sumber data primer diperoleh melalui observasi langsung, hasil dokumentasi, serta bantuan anak-anak usia dini yang sedang melakukan kegiatan Penanaman Nilai-nilai Religius, dalam hal ini Anak-anak TK Dharma Wanita Tibo. Kecamatan Sindue Tombusabora Kabupaten Donggala yang menjadi subyek penelitian.

Teknik pengumpulan data yang digunakan adalah teknik observasi, dokumentasi dan wawancara. Adapun teknik analisis data yang dilakukan meliputi reduksi data, penyajian data dan verifikasi data. Data-data yang telah didapatkan dari lokasi penelitian sangat penting untuk dicek kembali, agar benar-benar memperoleh data yang akurat sesuai harapan. Empat kriteria yang menunjukkan keabsahan suatu data, yang menurut Lexy J. Moelong adalah 'derajat kepercayaan (credibility), keteralihan (transferability), ketergantungan (dependability) dan kepastian (konfirmality). ${ }^{7}$ Selanjutnya, untuk mengecek keabsahan data yang diperoleh maka dilakukan tehnik pemeriksaan atau pengecekan data yang memanfaatkan sesuatu yang lain, diluar data itu untuk keperluan pengecekan dan perbandingan. Menurut sugiyono, Tiga macam triangulasi sebagai tehnik pemeriksaan yaitu "triangulasi dengan sumber, triangulasi dengan tehnik pengumpulan data, triangulasi waktu. ${ }^{8}$

\section{HASIL DAN PEMBAHASAN}

\section{A. Implementasi dan Bentuk Penanaman Nilai Karakter Religius Pada Anak Usia Dini di TK Dharma Wanita Tibo Kecamatan Sindue Tombusabora Kabupaten Donggala}

1. Upaya guru dalam mengimplementasikan nilai-nilai religius pada anak usia dini

Sebelum masuk kedalam kelas, setiap pagi guru menyuruh anak-anak untuk berbaris di depan halaman sekolah dan guru menyampaikan beberapa arahan-arahan kepada mereka. Kemudian setelah selesai berbaris guru mempersilahkan anak-anak untuk masuk kedalam kelas masing-masing. Sebelum memulai pembelajaran terlebih dahulu guru mengingatkan anak-anak untuk untuk selalu berdo'a sebelum memulai

\footnotetext{
${ }^{7}$ Lexy J. Moleong, Metodologi Penelitian Kualitatif (Bandung : Rosdakarya), 115

8 Sugiyono, Metode Penelitian Pendidikan Pendekatan Kuantitaf, Kualitatif Dan R\&D (Cet.XX;Bandung: Alfabet, 2014), 179.
} 
segala aktivitas, adapun do'a yang selalu dibaca setiap memulai pembelajaran yaitu do'a kepada kedua orang tua, do'a belajar, dan do'a kebaikan dunia dan akhirat. Setelah selesai berdo'a guru memberikan salam dan menyapa anak-anak, lalu bernyayi agar mereka merasa bahagia dan senang. Setelah itu guru menyampaikan tema hari ini. Sebagaimana dijelaskan salah satu informan berikit ini:

TK Dharma Wanita Tibo Kecamatan Sindue Tombusabora Kabupaten Donggala, mengajarkan anak-anak tentang nilai keimanan,nilai ibadah dan nilai akhlak. ${ }^{9}$

Berdasarkan pernyatan di atas, penulis dapat menarik kesimpulan bahwa TK Dharma Wanita Tibo Kecamatan Sindue Tombusabora Kabupaten Donggala mengajarkan anak-anak tentang nilai keimanan, nilai ibadah dan nilai akhlak. Dalam mengajarkan nilai keimanan kepada anak-anak perlunya guru mempersiapkan lagulagu tentang keimanan, karena dengan lagu itulah anak-anak bisa mengetahui bahwa dunia ini ada yang menciptakannya yaitu Allah Swt. Keadaan tersebut juga ditegaskan oleh salah seorang informan berikut:

Dalam mengajarkan anak-anak dengan nilai keimanan, sebelum memulai pembelajaran guru dan anak-anak bernyanyi lagu-lagu tentang tauhid contohnya lagu Asmaul Husna atau nama-nama Allah Swt. Dengan cara ini anak dapat mengenal siapa penciptanya dan menumbuhkan keyakinan dalam dirinya tentang keimanan yang diajarkan oleh guru. ${ }^{10}$

Berdasarkan pernyataan tersebut dapat diketahui bahwa guru-guru di TK Dharma Wanita Tibo Kecamatan Sindue Tombusabora Kabupaten Donggala, mengajarkan anak-anak tentang nilai keimanan, sebelum memulai pembelajaran guru dan anak-anak bernyayi lagu-lagu tentang tauhid contohnya lagu Asmaul Husna atau nama-nama Allah Swt. Dengan cara ini anak diharapkan dapat mengenal siapa pencipta mereka dan mampu menumbuhkan dalam dirinya tentang keimanan yang diajarkan oleh gurunya dan dapat merealisasikan dalam kehidupan sehari-hari. Begitu pula pernyataan salah seorang informan berukut ini:

9 Sulina, Guru Kelas , 'Wawancara'” , Tibo Kecamatan Sindue Tombusabora;Ruang Guru, Tanggal 11 April 2019, Pukul 09.30 Sampai Selesai.

${ }^{10}$ Sulina, Guru Kelas, “Wawancara” ,Tibo Kecamatan Sindue Tombusabora ;Ruang Guru, Tanggal 11 April 2019, Pukul 09.30 Sampai Selesai. 
Dalam mengajarkan nilai ibadah, guru mengenalkan huruf hijayyah pada setiap hari jum'at, agar anak-anak bisa membaca Al-Qur'an dengan benar. ${ }^{11}$

Dari pernyataan di atas dapat kita simpulkan bahwa pada setiap hari jum'at guru mengenalkan kepada anak-anak huruf hijayyah, agar mereka dapat membaca Al-Quran dengan benar. Mengajarkan nilai ibadah kepada anak-anak dengan mengenalkan huruf hijayyah, selain itu juga anak harus dikenalkan dengan rukun shalat khususnya shalat lima waktu, anak yang berumur 2 tahun atau TK baik diberikan pelajaran-pelajaran sejak dini karena anak mampu mengingat dan menangkap pelajaran dengan cepat. Sebagaimana pernyataan seorang informan ini:

Dalam mengajarkan nilai akhlak kepada anak-anak, guru membiasakan mereka untuk selalu membaca doa kedua orang tua sebelum memulai pembelajaran untuk setiap harinya, guru juga memberikan arahan-arahan kepada anak-anak jangan durhaka kepada kedua orang tua, jangan membentak mereka, karena kedua orang tua yang sudah melahirkan dan merawat kita dari kecil hingga dewasa. ${ }^{12}$

Dari pernyatan di atas dapat kita simpulkan bahwa sebelum memulai pembelajaran guru membiasakan kepada anak-anak untuk berdoa kepada Allah untuk kedua orang tua, guru juga memberikan arahan kepada mereka jangan membentak ibu pabak, jangan durhaka kepada keduanya, karena keduanya yang telah melahirkan dan merawat kita dari kecil hingga dewasa. Pernyataan di atas mengajarkan nilai akhlak kepada anak-anak dengan cara mendo'akan kedua orang tua, selain itu juga anak harus diajarkan dengan tata cara adab makan, adab minum, adab berpakaian, adab berteman, dan adab kepada kedua orang tua. Dari pernyataan-pernyataan di atas dapat penulis simpulkan bahwa di TK Dharma Wanita Tibo Kecamatan Sindue Tombusabora Kabupaten Donggala. Mengajarkan kepada anak-anak tentang nilai keimanan, nilai ibadah, dan nilai akhlak. selain itu, guru juga mengajarkan kepada mereka bahwa dalam berbicara harus mengatakan perkatan yang baik contohnya iye dalam menjawab perkataan dan tidak boleh mengatakan perkataan iyo.

Pada setiap kelas, wali kelas ataupun guru-guru lainnya bertanggung jawab terhadap lancarnya proses pembelajaran. Wali kelas ataupun guru-guru lainnya dapat memperhatikan tingkah laku anak-anak saat mereka di dalam kelas maupun di luar kelas agar proses pembelajaran dapat terarah lebih baik.

\footnotetext{
${ }^{11}$ Ninang, Guru Kelas, “Wawancara”, Tibo Kecamatan Sindue Tombusabora ;Ruang Guru, Tanggal 12 April 2019, Pukul 09.30 Sampai Selesai.

12 Ninang, Guru Kelas, “Wawancara”, Tibo Kecamatan Sindue Tombusabora ;Ruang Guru, Tanggal 12 April 2019, Pukul 09.30 Sampai Selesai.
} 
Sama halnya dengan beberapa pernyataan informan yang lain bahwa mereka sependapat dengan apa yang dituturkan oleh salah seorang informan di atas. Menurut mereka dengan diajarkan tentang nilai keimanan, nilai ibadah, dan nilai akhlak, dapat mengenal Allah Swt dan membentuk perilaku mereka agar lebih baik.

Dalam proses pembelajaran guru dituntut dapat mencerdasarkan dan memberbaiki nilai-nilai religius anak-anak, dalam hal ini yang telah direncanakan oleh guru- guru di TK Dharma Wanita Tibo Kecamatan Sindue Tombusabora Kabupatn Donggala yaitu dengan memakai panduan kurikulum atau yang dikenal dengan istilah dalam pembelajaran TK RPPM (Rencana Pelaksaaan Pembelajaran Mingguan) dan RPPH (Rencana Pelaksaan Pembelajaran Harian) dalam hal ini guru menggunakan RPPM dan RPPH guna agar pembelajaran dapat terarah lebih baik dan tersususun rapi. Sebagaimana pernyatan informan berikut ini:

Kami para guru memiliki panduan dalam mengajar yang disebut Rencana Pelaksanaan Pembelajaran Mingguan (RPPM) dan Rencana Pelaksanaan Pembelajaran Harian (RPPH), didalamnya sudah ada alokasi waktu dalam penyampaian materi pada setiap pertemuan. Jadi kami bisa menentukan target apa yang ingin dicapai bagi anak-anak pada pertemuan selanjutnya. Pada setiap pertemuannya juga kami mengatur waktu bagi penyampaian materi, pemberian tugas, diskusi dan membuka dan menutup pembelajaran. Dengan cara seperti ini, kegiatan mengajar kami jadi lebih fokus dan terarah. Dalam pelaksanaan pembelajaran kami para guru sebelum masuk kedalam kelas anak-anak berbaris di halaman sekolah kemudian masuk dengan tertib dan sebelum belajar anak-anak berdo'a terlebih dahulu, karena do'a adalah suatu interaksi antara kita terhadap sang pencipta. ${ }^{13}$

Berdasarkan pernyataan tersebut dapat diketahui bahwa guru-guru di TK Dharma Wanita Tibo Kecamatan Sindue Tombusabora Kabupaten Donggala dalam mengoptimalkan aktivitas mengajarnya dengan membuat RPPM dan RPPH. Hal ini dirasa lebih efisien karena mereka bisa mengajar dengan terarah dan memiliki target yang jelas pada setiap pertemuannya. Alokasi waktu yang direncanakan pada setiap pertemuannya, jika terlaksana sesuai dengan RPPM dan RPPH memungkinkan tercapainya target penguasaan materi yang ingin dicapai bagi anak-anak. Kondisi ini tentunya akan berimbas kepada peningkatan kemampuan anak-anak itu sendiri.

Anak-anak merupakan individu yang memiliki potensi dan kemampuan yang berbeda antara yang satu dengan yang lainnya. Keadaan ini perlu disadari oleh guru sebagai tenaga pendidik. Dengan menyadari kondisi ini, guru tidak akan lagi mendiskriminasikan anak-anak yang pandai, kurang pandai atau tidak pandai. Tetapi

13 Yuliastri, Guru Kelas, 'Wawancara', Tibo Kecamatan Sindue Tombusabora ;Ruang Guru, Tanggal 13 April 2019, Pukul 09.30 Sampai Selesai. 
guru tersebut akan berupaya memikirkan teknik apa yang harus digunakan agar semua anak-anak mengerti dan memahami tema pelajaran yang diberikan. Guru hendaknya mempersiapkan teknik yang beragam pada setiap pertemuannya agar tidak terkesan monoton dan membosankan.

2. Bentuk penanaman karakter religius pada anak usia dini

Dalam kehidupan sehari-hari tentunya kita mempunyai karakter, Pada bagian ini penulis akan memaparkan hasil pengamatan serta hasil wawancara dari berbagai informan. Pengamatan dan wawancara yang dilakukan, yaitu untuk mengetahui sejauh mana anak-anak menerapkan bentuk nilai karakter religius kepada mereka. Dan penulis akan menguraikan berberapa bentuk nilai karakter di antaranya : 1. Jujur, 2. Tanggung jawab, 3. Disiplin, 4. Hidup sehat, 5. Peduli alam, 6. Peduli sosial. Sebagaimana perkataan informan berikut ini:

Jujur adalah perkataan yang benar dan tidak berbohong, contohnya ingin uang harus minta sama ibu, jangan langsung diambil begitu saja, lihat uang teman tidak boleh diambil tapi harus meminta dulu sama temannya. $^{14}$

Dari pernyataan di atas dapat disimpulkan bahwa, jujur adalah perkataan yang benar dan tidak berbohong contohnya ingin uang harus minta sama ibu terlebih dahulu, lihat uangnya teman tidak boleh langsung diambil tetapi harus meminta terlebih dahulu kepada temannya jangan langsung diambil atau mengambil sembunyi-sembunyi tanpa diketahui dari pemiliknya berarti pencuri dan tidak jujur.

Tanggung jawab adalah perkataan yang benar dan yang dilakukan,contohnya anak harus belajar degan rajin agar cepat pintar. ${ }^{15}$

Dari pernyataan di atas dapat ditarik kesimpulan bahwa tanggung jawab adalah perkataan yang benar dan yang harus dilakukan contoh seorang anak jika ingin pintar maka mereka harus belajar dengan rajin dan tidak boleh malas agar dapat membuat orang tua banggga.

Disiplin adalah tepat waktu dalam melakukan segala hal contohnya anak mempunyai tugas dari gurunya dan harus dikerjakan tepat waktu, bangun pagi-pagi dan bersiap-siap kesekolah. ${ }^{16}$

\footnotetext{
${ }^{14}$ Selfa, Siswa, ' Wawancara'” Tibo Kecamatan Sindue Tombusabora;Ruang Kelas, Tanggal 11 April 2019, Pukul 10.30 Sampai Selesai.

15 Kastila, Siswa, 'Wawancara"' Tibo Kecamatan Sindue Tombusabora;Ruang Kelas, Tanggal 11 April 2019, Pukul 10.30 Sampai Selesai.

16 Kastila, Siswa, 'Wawancara', Tibo Kecamatan Sindue Tombusabora;Ruang Kelas, Tanggal 12 April 2019, Pukul 10.30 Sampai Selesai.
} 
Dari pernyatan di atas dapat disimpulkan bahwa disiplin adalah tepat waktu dalam melakukan segala hal contoh seorang anak mempunyai tugas dari sekolah yang diberikan oleh gurunya, anak harus mengerjakan tugasnya tepat waktu. Bangun pagipagi dan bersiap berangkat kesekolah.

Hidup sehat adalah pola hidup seseorang yang merawat hidupnya atau dirinya sendirinya contohnya makan makanan yang bergizi, olaraga. ${ }^{17}$

Dari pernyataan di atas dapat disimpulkan bahwa hidup sehat adalah pola hidup seseorang yang merawat hidupnya atau tubuhnya sendiri dalam menjalani kehidupan sehari-hari contonya makan makanan yang bergizi seperti makanan empat sehat lima sempurna, yang didalamnya banyak manfaat bagi tubuh kita, olaraga yang teratur agar tubuh kita menjadi kuat dan sehat.

Peduli alam adalah memperhatikan lingkungan alam sekitar contohnya membuang sampah pada tempatnya, membersihkan halaman sekolah. ${ }^{18}$

Dari pernyataan di atas dapat ditarik kesimpulan bahwa peduli alam adalah memperhatikan lingkungan alam sekitar contoh membuang sampah pada tempatnya, membersihkan halaman sekolah agar terlihat indah dan bersih juga tidak terjangkit penyakit.

Peduli sosial adalah memperhatikan orang lain tanpa melihat sudut pandang mereka contohnya membantu sesama teman saat mereka kesusahan. ${ }^{19}$

Dari pernyataan di atas dapat disimpulkan bahwa peduli sosial adalah memperhatikan orang lain tanpa melihat sudut pandang mereka contohnya tolong menolong sesama teman saat mereka dalam kesusahan dan tidak minta pabri dalam membantu mereka.

Dari uraian di atas bahwa ada enam karakter religius yang ditanamkan di TK Dharma Wanita Tibo Kecamatan Sindue Tombusabora Kabupaten Donggala. Diharapkan para guru dan orang tua untuk selalu membimbing dan mengarahkan anakanak untuk membentuk karakter mereka, agar ketika dewasa mereka dapat berakhlak yang baik dan berbudi pekerti yang luhur.

${ }^{17}$ Selfa, Siswa, ' Wawancara'” Tibo Kecamatan Sindue Tombusabora;Ruang Kelas, Tanggal 12 April 2019, Pukul 10.30 Sampai Selesai.

${ }^{18}$ Selfa, Siswa, 'Wawancara'” Tibo Kecamatan Sindue Tombusabora;Ruang Kelas, Tanggal 13 April 2019, Pukul 10.30 Sampai Selesai.

19 Kastila, Siswa, 'Wawancara', Tibo Kecamatan Sindue Tombusabora;Ruang Kelas, Tanggal 13 April 2019, Pukul 10.30 Sampai Selesai. 


\section{B. Faktor Pendukung dan Penghambat Implementasi Penanaman Nilai-nilai Religius Pada Anak Usia Dini di TK Dharma Wanita Tibo Kecamatan Sindue Tombusabora Kabupaten Donggala.}

Pada setiap upaya atau usaha yang dilakukan dalam bidang apapun pastinya memilki faktor pendukung dan penghambaat tercapainya tujuan dari usaha tersebut, tidak terkecuali dengan implementasi penanaman nilai-nilai religius pada anak usia dini di TK Dharma Wanita Tibo Kecamatan Sindue Tombusabora Kabupaten Donggala. Menurut salah seorang informan berikut membiasakan berbaris di TK Dharma Wanita Tibo Kecamatan Sindue Tombusabora Kabupaten Donggala dapat terlaksana dengan baik karena anak-anak di TK Dharma Wanita Tibo Kecamatan Sindue Tombusabora Kabupaten Donggala memilki guru yang bertanggung jawab terhadap anak-anak dan adanya kerja sama antara guru dan orang tua. Berikut pemaparannya:

Sebagai seorang guru/pendidik kita tidak boleh berputus asa dalam mengajarkan anak-anak tentang hal-hal yang baik dan bermanfaat baginya, bagaimanapun nilai-nilai religius anak-anak sangat penting dibentuk/bimbing agar anak-anak ketika besar dapat beraklakul karimah dan tidak mudah bergaul dengan siapa saja dan dapat mengkondisikan diri mereka terhadap lingkungan disekitar mereka. Nilai-nilai religius anak-anak perlu diterapkan pada diri anak-anak sejak kecil/buayan. oleh karena itu, sebagai seorang guru harus melakukan kerja sama antara guru dan orang tua dalam penanaman nilai-nilai religius pada anak usia dini dengan cara mengajarkan nilai keimanan, nilai ibadah dan nilai akhlak. ${ }^{20}$

Berdasarkan pernyataan tersebut dapat diketahui bahwa adanya rasa tanggung jawab serta adanya kerjasama antara guru dan orang tua menjadi salah satu faktor pendukung terlaksananya implementasi penanaman yang ditujukan untuk nilai-nilai religius pada anak usia dini. Lingkungan yang baik juga berperan penting dalam pembentukan akhlak anak-anak dan juga dari teman sebaya dapat memotivasi mereka dalam berakhlak yang baik dan dikehidupan sehari-harinya.

Selain faktor pendukung, dalam pembentukan akhlak di TK Dharma Wanita Tibo Kecamatan Sindue Tombusabora Kabupaten Donggala guna penanaman nilainilai religius pada anak usia dini juga terdapat faktor penghambat sehingga penanaman nilai-nilai religius tersebut dirasa kurang optimal. Dari keterangan informan berikut, dapat mengetahui faktor penghambat tersebut.

Faktor penghambat belum maksimalnya penananam nilai-nilai religius di TK Dharma Wanita Tibo Kecamatan Sindue Tombusabora Kabupaten Donggala yaitu anak-anak lebih banyak bermain, lingkungan, teman, dan

\footnotetext{
${ }^{20}$ Ninang, Guru Kelas, 'Wawancara', , Tibo Kecamatan Sindue Tombusabora ;Ruang Guru, Tanggal 15 April, Pukul 09.30 Sampai Selesai.
} 
kurangnya motivasi dari orang tua sebagai figur utama dalam pendidikan. Sehingga akhlak mereka masih belum bagus/kurang. ${ }^{21}$

Berdasarkan keterangan tersebut dapat diketahui bahwa faktor penghambat belum terlaksananya pembentukan akhlak secara maksimal di TK Dharma Wanita Tibo Kecamatan Sindue Tombusabora Kabupaten Donggala dalam penananam nilainilai religius pada anak usia dini yaitu anak-anak lebih banyak bermain dan kurangnya motivasi dari orang tua, pengaruh lingkungan juga dapat membuat akhlak anak-anak tidak baik, pengaruh teman sebaya juga dapat memotivasi mereka dengan tingkah laku teman-teman yang tidak baik. Oleh karena itu, orang tua tidak bisa lepas dari membimbing anak-anak mereka, karna anak-anak lebih banyak di rumah dari pada disekolah. Guru merupakan orang tua kedua dalam lingkungan sekolah, pendidikan utama yaitu orang tua, sebagai orang tua harus berperan penting dalam penanaman nilai-nilai religius pada anak usia dini. Oleh karena itu, harus ada kerjasama antara guru dan orang tua guna penanaman nilai-nilai religius anak usia dini yang lebih baik.

\section{KESIMPULAN}

Berdasarkan hasil penelitian dan pembahasan yang termuat dalam bab sebelumnya tentang implementasi penanaman nilai-nilai religius pada anak usia dini dapat disimpulkan,sebagai berikut:

1. Penanaman nilai-nilai religius haruslah diberikan kepada anak sejak usia dini seperti nilai keimanan, nilai ibadah, dan nilai akhlak. Maka akan memberikan nilai tersendiri kepada mereka. Anak akan terbiasa melaksanakan kewajiban mereka kepada Allah Swt dan akan berakhlak seperti Nabi Muhammad Saw. Anak akan merasa takut bila tidak melakukan kewajibannya. Maka perlunya kita sebagai orang tua maupun guru untuk selalu memberikan nasehat-nasehat yang baik terhadap anak.

2. Dalam memberikan mereka pelajaran, kita sebagai seorang guru harus memperhatikan dan tidak pilih kasih terhadap anak yang kurang cerdas, karna guru yang baik adalah guru yang bertangung jawab atas tugasnya

\section{SARAN}

Berdasarkan hasil penelitian yang telah dilakukan, yaitu tentang implementasi penanaman nilai-nilai religius pada anak usia dini, maka peneliti mengemukakan beberapa saran sebagai berikut:

1. Bagi anak usia dini, hendaknya memahami nilai keimanan, nilai ibadah, dan nilai akhlak, serta menerapkan dalam kehidupan sehari-hari. Selalu mendengarkan

${ }^{21}$ Ninang, Guru Kelas. 'Wawancara' Tibo Kecamatan Sindue Tombusabora ;Ruang Guru, Tanggal 15 April, Pukul 09.30 Sampai Selesai. 
perkataan ibu guru dan jangan membantah mereka, karena guru adalah orang tua kedua anak-anak.

2. Bagi guru dan orang tua, hendaknya selalu membimbing dan mengarahkan anakanak, agar mereka dapat menjadi anak yang baik yang berguna bagi orang lain dan bangsa dan masyarakat.

3. Bagi peneliti lain, seharusnya dapat mengambil hasil penelitian ini sebagai acuan untuk melaksanan penelitian selanjutnya dengan metode yang berbeda.

4. Bagi penulis, mengharapakan kritikan dan saran dari pembaca untuk perbaikan skripsi ini kedepan nantinya. Karena, penulis menyadari masih banyak kekurangan yang ada di dalam penyusunan dan pembahasan materi di dalam skripsi ini

\section{DAFTAR PUSTAKA}

Departemen Pendidikan Nasional, Undang-undang RI Nomor 20 Tahun 2003, Tentang Sistem Pendidikan Nasional, Pada Bab 1, Pasal 1, (2003).

Fatiyah Hasan Sulaiman, Sistem Pendidikan Versi Al-Ghazali, (Bandung: Al-Ma'arif, 1986).

Lexy J. Moleong, Metodologi Penelitian Kualitatif, (Bandung : Rosdakarya, 2010).

Muhammad Fadilah, Pendidikan Karakter Anak Usia Dini, (Yogyakarta: Ar-Ruzz Media, 2013).

Sri Harini, Mendidik Anak Sejak Dini, (Yogyakarta: Kreasi Wacana, 2003).

Sugiyono, Metode Penelitian Pendidikan Pendekatan Kuantitaf, Kualitatif Dan R\&D (Bandung : Alfabet, 2014).

Winda Gunarti, Metode Pengembangan Perilaku dan Kemampuan Dasar Anak Usia Dini, (Jakarta : Penerbit Universitas Terbuka, 2008) 